\title{
Virulence Genes and Resistance Profile of Escherichia coli Isolated in Meat Meal Samples*
}

\author{
Saruanna Millena dos Santos Clemente ${ }^{1}$, Érica Chaves Lúcio ${ }^{2}$, \\ Mércia Rodrigues Barros ${ }_{(}^{1}$, Sineide Maria de Oliveira Vilela ${ }^{3}$ \& José Wilton Pinheiro Junior ${ }_{(1}^{1}$
}

\begin{abstract}
Background: Feed is the main route of transmission of pathogenic microorganisms and is responsible for a large part of the cost of poultry production, so the inclusion of alternative foods in diets for monogastrics has been a constant. Among alternative foods most used in modern poultry farming are animal meal, however, when contaminated they constitute a route of transmission of several pathogenic agents, including Escherichia coli. In addition, there is a zoonotic potential, as poultry products are intended for human consumption. The objective of this research was to detect virulence genes, as well as to evaluate the resistance profile of Escherichia coli isolates from meat meal samples.

Materials, Methods \& Results: A total of 40 Escherichia coli isolates were analyzed and the virulence genes surveyed iss, ompT, hlyF, iutA, and fimA identified by Polymerase Chain Reaction (PCR). The antimicrobial agents tested were: amoxycillin $(30 \mu \mathrm{g})$, ceftiofur $(30 \mu \mathrm{g})$, ciprofloxacin $(5 \mu \mathrm{g})$, doxycycline $(30 \mu \mathrm{g})$, florfenicol $(30 \mu \mathrm{g})$, fosfomycin $(200 \mu \mathrm{g})$, gentamicin $(10 \mu \mathrm{g})$, norfloxacin $(10 \mu \mathrm{g})$ and oxacillin $(1 \mu \mathrm{g})$. It was possible to observe the occurrence of the iss resistance gene in $100 \%$ of Escherichia coli isolates, followed by hlyF (85\%), fimA (75\%), ompT (17.5\%) and iutA (5\%). Regarding the simultaneous detection for the genes, a greater association between the genes iss, $h l y F$ and fimA (60\%) was verified. All isolates showed resistance to oxacillin (100\%), followed by doxycycline (25\%), amoxicillin (22.5\%), norfloxacin (17.5\%), ceftiofur $(15 \%)$, florfenicol $(12.5 \%)$, fosfomycin $(12.5 \%)$, ciprofloxacin $(10 \%)$ and gentamycin $(2.5 \%)$. In this study, a variation of the multiple antimicrobial resistance index (IRMA) was observed between 0.22 and 0.77 .

Discussion: The indiscriminate use of of antimicrobials as performance enhancers in production animals, may have contributed to the increase in antimicrobial resistance, with the occurrence of multiresistant Escherichia coli carrying virulence genes. Virulence genes present in Escherichia coli isolates are studied to understand the degree of influence they exert in the establishment of the disease, one of the most researched genes is the iss gene, involved in the processes that promote serum resistance. In this study, iss $(100 \%)$ was present in all the isolates analyzed, although it is not the only mechanism used by these bacteria to reach internal organs and trigger an infection, this gene encodes an important mechanism associated with high levels of virulence. The second highest prevalence found was of the $h l y F$ gene $(85 \%)$, the high prevalence of $h l y F$ suggests virulence potential, involved with the production of hemolysin and improvement of outer membrane vesicles associated with the release of toxins. The fimA gene (75\%) was detected in a slightly lower percentage when compared to iss and $h l y F$. With the second lowest prevalence, the ompT gene $(17.5 \%)$, is involved in a process that includes the proteolytic degradation of antimicrobial peptides and with the lowest prevalence the iutA gene $(5 \%)$. Certain combinations of virulence genes make the strains easier to survive, adhere to, colonize and even the ability to develop septicemic conditions. Multiresistant E. coli strains, is a fact of concern for both animal and human health, since the presence of multiresistant strains, originating from poultry, can be transmitted from chicken carcasses. In this sense, the importance of sanitary control of the inputs used in animal feed is emphasized, as well as the prudent use of antimicrobials in animal production, with a view to producing a safe food, minimizing not only the economic losses, but also the risks to human health.
\end{abstract}

Keywords: antimicrobial, bacterial resistance, colibacillosis, poultry.

DOI: $10.22456 / 1679-9216.114233$

"Article based on a Thesis submitted by the senior author in partial fulfillment of requirements for the Master of Science Degree. ${ }^{1}$ Department of Veterinary Medicine, Rural Federal University of Pernambuco (UFRPE), Recife, PE, Brazil. ${ }^{2}$ School of Veterinary Medicine and Animal Science (EMVZ), Federal University of Bahia (UFBA), Salvador, BA, Brazil. ${ }^{3}$ Animal Diagnostic Laboratory (LADA), Caruaru, PE. CORRESPONDENCE: S.M.S. Clemente [saruannamillena@ hotmail.com]. Department of Veterinary Medicine - UFRPE. Rua Dom Manoel de Medeiros s/n. CEP 52171-900 Recife, PE, Brazil. 


\section{INTRODUCTION}

The alternative foods most used in modern poultry farming are animal meal, which is an important source of protein and energy. However, when contaminated, it becomes a transmission route for several pathogenic agents, including bacteria responsible for serious damage to animal and human health, such as Salmonella spp., Campylobacter spp. and Clostridium spp., with emphasis on Escherichia coli [33].

Some bacteria, especially E. coli, have the ability to transmit the virulence genotype to other bacteria through mobile genetic elements [29]. In this sense, studies correlate avian strains with $E$. coli strains that cause disease in humans and suggest a zoonotic potential of APEC strains [6,27]. Another concern is the use of antimicrobials as performance enhancers in production animals, as it favors the increase of antimicrobial resistance, in addition, it is possible that these bacteria and their virulence genes are transmitted and incorporated into the human microbiota, thus reducing the effectiveness of antimicrobial treatment [10].

In view of the above, we highlight the relevance of the knowledge about the occurrence of virulence genes in E. coli isolates and the sensitivity profile of the most commonly used antimicrobials in industrial poultry, since the rations and their raw materials, especially those of animal origin, represent an important route of transmission when contaminated by potentially pathogenic agents, a fact that causes serious damage to the poultry sector and is relevant for public health.

\section{MATERIALS AND METHODS}

\section{Samples}

A total of 40 Escherichia coli isolates, stored at $-20^{\circ} \mathrm{C}$ in $20 \%$ Brain Heart Infusion (BHI) ${ }^{1}$, belonging to a biological sample bank of the Animal Diagnostic Laboratory - LADA, located in the state of Pernambuco, Brazil, were analyzed.

\section{Reactivation of Escherichia coli isolates}

The isolates were transferred to BHI broth ${ }^{1}$ and incubated at $37^{\circ} \mathrm{C}$ for $16-18 \mathrm{~h}$ then were seeded in agar Levine $^{2}$ and subjected to the same incubation conditions. The colonies were confirmed by Gram staining and biochemical tests: triple sugar iron (TSI) citrate, methyl red (VM), Voges Proskauer (VP) indole, motility, hydrogen sulphide production in agar Sulphate/
Indol/Motility (SIM) [8]. For all tests, the E. coli strain ATCC (25922) was used as a positive control.

Determination of the resistance profile

The resistance profile was determined using the disk diffusion test according to the protocol described in the Clinical and Laboratory Standards Institute [11]. The tested antibiotics ${ }^{3}$ were: amoxicillin $(30 \mu \mathrm{g})$, ceftiofur $(30 \mu \mathrm{g})$, ciprofloxacin $(5 \mu \mathrm{g})$, doxycycline $(30 \mu \mathrm{g})$, enrofloxacin $(5 \mu \mathrm{g})$, florfenicol $(30 \mu \mathrm{g})$, fosfomycin $(200 \mu \mathrm{g})$, gentamicin $(10 \mu \mathrm{g})$, nalidixic acid $(30 \mu \mathrm{g})$, norfloxacin $(10 \mu \mathrm{g})$ and oxacillin $(1 \mu \mathrm{g})$. The multiple antimicrobial resistance index (IRMA), this index was determined by the ratio between the number of antimicrobials in which isolates exhibited resistance and the total number of antimicrobials [22].

\section{Determination of virulence genotype}

For determination of virulence genotype of the isolates, the DNA was extracted by the thermoextraction method [12]. After extraction, the genetic material was submitted to the Polymerase Chain Reaction (PCR) technique uniplex. The primers and amplification cycles were according to the references, described in Table 1. For the negative control of the reactions, ultrapure water was used and as positive controls, well-known and sequenced samples from the Federal Rural University of Pernambuco (UFRPE) were used. The amplified DNA was subjected to agarose electrophoresis gel ${ }^{2}(1 \%)$, stained with Blue Green $^{4}$, visualized under UV light and documented by an image capture system ${ }^{5}$.

\section{RESULTS}

The occurrence of the iss virulence gene in $100 \%$ (40/40) of Escherichia coli isolates was observed, followed by hlyF 85\% (34/40), fimA 75\% (30/40), ompT $17.5 \%$ (7/40) and iutA 5\% (2/40). The data for the isolated or simultaneous detection for the genes under study are set out in Table 2, with a higher occurrence of association between the iss, hlyF and fimA genes with $60 \%(24 / 40)$.

The resistance profile of $E$. coli isolates against commercial antimicrobials is shown in Table 3. All isolates showed resistance to oxacillin $(100 \%)$, followed by doxycycline $(25 \%)$, amoxicillin $(22.5 \%)$. The most effective antimicrobial among the isolates tested was gentamicin $(97.5 \%)$; ceftiofur, ciprofloxacin and fosfomycin had the same percentage of sensitivity (85\%). All 
S.M.S. Clemente, E.C. Lúcio, M.R. Barros, S.M.O. Vilela \& J.W. Pinheiro Júnior. 2021. Virulence Genes and Resistance Profile of

isolates tested were resistant to at least 1 antimicrobial. Regarding the multiresistance profile, $27.5 \%$ (11/40) of the strains were resistant to a minimum of 3 and a maximum of 7 antimicrobials. In this study, a variation of the multiple antimicrobial resistance index (IRMA) was observed between 0.22 and 0.77 .

Table 1. Description of the genes, primers and references used in the study to identify the virulence profile of Escherichia coli isolates

\begin{tabular}{|c|c|c|c|}
\hline Genes & Sequence of the primers $\left(5^{\prime}-3{ }^{\prime}\right)$ & $\mathrm{N}^{\circ}$ of base pairs & Reference \\
\hline \multirow{2}{*}{ iss } & CAGCAACCCGAACCACTTGATG & \multirow{2}{*}{323} & \multirow{2}{*}{ [19] } \\
\hline & AGCATTGCCAGAGCGGCAGAA & & \\
\hline \multirow{2}{*}{ ompT } & ATCTAGCCGAAGAAGGAGGC & \multirow{2}{*}{559} & \multirow{2}{*}[32]{} \\
\hline & CCCGGGTCATAGTGTTCATC & & \\
\hline \multirow{2}{*}{$h l y F$} & GGCGATTTAGGCATTCCGATACTC & \multirow{2}{*}{599} & \multirow{2}{*}[18]{} \\
\hline & ACGGGGTCGCTAGTTAAGGAG & & \\
\hline \multirow{2}{*}{ iutA } & GGCTGGACATCATGGGAACTGG & \multirow{2}{*}{302} & \multirow{2}{*}{ [19] } \\
\hline & CGTCGGGAACGGGTAGAATCG & & \\
\hline \multirow{2}{*}{ fimA } & GTTGATCAAACCGTTCAG & \multirow{2}{*}{540} & \multirow{2}{*}[24]{} \\
\hline & AATAACGCGCCTGGAACG & & \\
\hline
\end{tabular}

Table 2. Occurrence of association of the genes iss, hlyF, fimA, ompT and iutA in 40 Escherichia coli isolates from meat meal.

\begin{tabular}{|c|c|c|}
\hline Genes & $\mathrm{n}$ & $\%$ \\
\hline \multicolumn{3}{|l|}{1} \\
\hline iss & 5 & 12.5 \\
\hline \multicolumn{3}{|l|}{2} \\
\hline$h l y F+i s s$ & 2 & 5 \\
\hline fimA+iss & 1 & 2.5 \\
\hline \multicolumn{3}{|l|}{3} \\
\hline iss + hlyF+ompT & 2 & 5 \\
\hline$i s s+h l y F+f i m A$ & 24 & 60 \\
\hline$i s s+h l y F+i u t A$ & 1 & 2.5 \\
\hline \multicolumn{3}{|l|}{4} \\
\hline$i s s+h l y F+o m p T+f i m A$ & 4 & 10 \\
\hline \multicolumn{3}{|l|}{ All genes } \\
\hline$i s s+h l y F+o m p T+i u t A+f i m A$ & 1 & 2.5 \\
\hline Total & 40 & 100 \\
\hline
\end{tabular}

Table 3. Resistance profile of 40 Escherichia coli isolates from meat meal.

\begin{tabular}{|c|c|c|c|c|}
\hline \multirow{2}{*}{ Pharmacological Class } & \multirow{2}{*}{ Antimicrobial } & \multicolumn{3}{|c|}{ Resistance profile } \\
\hline & & Sensitive & Intermediate & Resistant \\
\hline Cephalosporins & Ceftiofur & $34(85 \%)$ & - & $6(15 \%)$ \\
\hline \multirow{4}{*}{ Quinolones } & Ciprofloxacin & $34(85 \%)$ & $2(5 \%)$ & $4(10 \%)$ \\
\hline & Norfloxacin & $33(82.5 \%)$ & - & $7(17.5 \%)$ \\
\hline & Enrofloxacin & $29(72.5 \%)$ & $2(5 \%)$ & $9(22.5 \%)$ \\
\hline & Nalidixic Acid & $22(55 \%)$ & $2(5 \%)$ & $16(40 \%)$ \\
\hline Fosfomycins & Fosfomycin & $34(85 \%)$ & $1(2.5 \%)$ & $5(12.5 \%)$ \\
\hline Tetracycline & Doxycycline & $22(55 \%)$ & $8(20 \%)$ & $10(25 \%)$ \\
\hline Aminoglycosides & Gentamicin & $39(97.5 \%)$ & - & $1(2.5 \%)$ \\
\hline \multirow{3}{*}{ Penicillin } & Amoxicillin & $27(64.5 \%)$ & $4(10 \%)$ & $9(22.5 \%)$ \\
\hline & Oxacillin & - & - & $40(100 \%)$ \\
\hline & Florfenicol & $33(82.5 \%)$ & $2(5.0 \%)$ & $5(12.5 \%)$ \\
\hline
\end{tabular}




\section{DISCUSSION}

In this study, some of the most frequent virulence genes were investigated, in which an occurrence of $100 \%$ was obtained for the iss gene in the isolates analyzed. This gene also showed high prevalence in comparative studies between APEC strains and isolates from healthy birds [16,31]. The gene iss, is one of the genes most searched in APEC strains, involved in mechanisms that allow the escape of the bacteria from the action of the complement system and the process of phagocytosis, during infection [1].

Although not the only mechanism used by $E$. coli to target organs and trigger infection, the iss gene has been associated with high levels of virulence. A survey conducted in different regions of Brazil, with E. coli isolates from suspected colibacillosis in birds, obtained prevalences of $78.6 \%, 63.2 \%, 58.8 \%$ and $46.2 \%$ of the iss gene in the South-West, South-East and Northeast regions respectively [7]. Due to the high prevalence of colibacillosis, the presence of this gene in isolates from flours of animal origin may serve as a risk indicator for the use of this raw material in the preparation of feed.

Found as the second largest occurrence, the $h l y F$ gene was detected in $85 \%$ of the isolates analyzed. Similar prevalences were obtained in other studies, with $78.2 \%, 68.8 \%$ and $70.3 \%$ [7,17,23]. Coded by ColV plasmid, the $h l y F$ gene is used as an epidemiological marker of APEC [14]. Involved with hemolysin production and enhancement of outer membrane vesicles (OMVs), $h l y F$ is associated with the release of toxins, responsible for promoting lesions in infected hosts [30]. Complementary studies should be performed to verify if the isolates of this research produce toxins, as well as to verify the pathogenicity of the same, which would imply in a greater risk for the use of these meat meals in the elaboration of rations.

The fimA gene was detected in $75 \%$ of the isolates, a slightly lower percentage when compared to the iss and $h l y F$. A similar result was found in strains of $E$. coli isolated in chickens with a form of colibacillosis, swollen head syndrome, with a prevalence of $64.3 \%$, responsible for adhesion and antigen-binding proteins, this gene plays an important role during infection [25].

With an occurrence of $17.5 \%$ the ompT gene is involved in a process that includes the proteolytic degradation of antimicrobial peptides (AMPs). Some foodborne pathogens, such as E. coli, cause severe diarrheal diseases, and to colonize the intestine, these pathogens must overcome innate immune defenses, such as antimicrobial peptides (AMPs) [35].

The iutA gene had a lower occurrence, this gene plays a relevant individual action, this action was identified in a study that induced suppression of the iutA gene, and consequently a significant decrease in the pathogenicity of strains of E. coli in the presence of infection in chickens free of pathogens (SPF) [15].

In addition, one study demonstrated an association between the ability to transport the iutA gene with antimicrobial resistance, strains capable of transporting papC or iutA genes were resistant to at least one of the antibiotics tested. In the multivariate analysis, the presence of the iutA gene was one of the factors that contributed independently for the strains to be resistant to ampicillin and tetracycline [20].

Among isolates of APEC obtained from birds with colibacillosis in Zimbabwe, the 3 most prevalent virulence genes were iutA (80\%), fimH (33.3\%) and hlyF (24.4\%), kpsM, pstB and ompT had the lowest prevalence, detected in only $2.2 \%$ of the isolates [26]. In Egypt, the prevalence of iroN, ompT, $h l y F$, iss and iutA genes ranged from $89.5 \%$ to $94.7 \%$ among APEC strains, while the prevalence among $E$. coli strains isolated in batches of healthy chicken ranged from $10 \%$ to $25 \%$ and in commensal strains (AFEC) between $46.6 \%$ and $53.3 \%$ [16]. The iutA and iss genes are also indicated as molecular markers of virulence for differentiation of strains causing necrotic dermatitis in broilers [9].

In a study carried out with isolates of $E$. coli in Brazil, with broilers and commercial laying hens produced in the State of Pernambuco, it was evidenced that the genes hlyF $66.6 \%$, ompT $66.6 \%$ and iss $75 \%$ presented higher occurrence in the infraorbital sinuses, while that for the cecal content isolates, the genes fimA $52.2 \%$ and iutA $30.4 \%$ were the most frequent in the infraorbital sinuses [4]. Considering the data obtained in the 2 studies carried out in the state of Pernambuco, it can be inferred that the field and input isolates used in the diet present virulence factors that may affect poultry plant health and cause economic losses.

Virulent strains of APEC from different origins showed a higher occurrence of plasmid colV genes (iroN, ompT, hlyF, iss and iutA) when compared to non-pathogenic $E$. coli strains from apparently healthy poultry litter [31]. These studies highlight the relevance 
of the genes involved in the infectious processes with E. coli, and reinforce the relationship with potentially pathogenic strains.

In this study, the most found genetic combination was iss $+h l y F+f i m A$, present in $60 \%$ of all isolates and $12.5 \%$ showed only the iss gene. The combination of sitAP+ompT+hlyF+iroN genes with $E$. coli strains isolated from birds with septicemia and absent in commensal strains [14]. This finding highlights the possibility of the identification of pathogenic strains to the detriment of the association of certain virulence genes. In another study, the combinations of iroN+fim $C+o m p T+h l y F+i u c D+i s s+f y u A$, irp2 + tsh $+i r o N+$ fim $C+o m p T+h l y F+i u c D+i s s+t s h$ and iroN+fimC+ompT+hlyF+iss were the most frequent, with $22.8 \%, 21.8 \%$ and $11.9 \%$, respectively [17].

Certain combinations of virulence genes confer the greatest strains on survival, adherence, colonization, and even the ability to develop septicemia, the differentiation of pathogenic strains of E. coli from commensals may be through the identification of specific combinations of genes [2].

Multidrug-resistant strains of E. coli show a concern for both animal and human health, since the presence of multiresistant strains from domestic poultry can be transmitted from chicken carcasses [34]. The hypothesis of virulence gene transfer and resistance to human ExPEC suggests the zoonotic ability of strains present in chicken products [13].

A survey conducted in Canada, when evaluating ExPEC strains from chicken meat, obtained a similarity level of 55-70\% when compared to ExPEC strains isolated from human cultures, with prevalences of $52.3 \%, 97.73 \%$ and $56.8 \%$ for iss, iutA and ompT, respectively [3]. These studies demonstrated a similarity between $E$. coli strains of different origins and emphasize the importance of this fact for public health, as well as the increasing antimicrobial resistance presented by such pathogenic strains.

The percentage of resistance, found in this study, was $100 \%$ to oxacillin, this can be justified due to the excessive use of this penicillin in the treatment of infections, in the region studied; as for multiresistance, $57.5 \%$ of isolates were resistant to more than 1 antimicrobial drug and $27.5 \%$ of resistant isolates from 3 to 7 antimicrobial drugs. In Brazil, the susceptibility of E. coli strains from human sources and food products of animal origin was analyzed in a study developed in Bahia, where $26 \%, 20.2 \%, 15.4 \%$ and $6 \%$ of the isolates were resistant to tetracycline, ampicillin, sulfamethoxazole/trimethoprim and cephalothin, respectively; in addition, $22 \%$ of the isolates showed resistance to more than 1 antimicrobial and found that E. coli from humans and food are resistant to commonly used antibiotics [28].

In Pernambuco, isolates of E. coli from broilers and commercial laying hens, presented $94.2 \%$ of multiresistance, being resistant to 3 or more antimicrobials belonging to different groups and the presence of detected plasmids demonstrated a possible association with antimicrobial resistance. In relation to multiple antimicrobial resistance indices, showed a variation between 0.07 and 1 in E. coli isolates [5]. Results close to the ones found in this study, with IRMA between 0.22 and 0.77 , are worrying, since there is a possibility of transmission of multiresistant strains to humans, through food of animal origin or through direct contact, when refers to risk groups such as field workers and veterinarians.

Before the evaluation by pharmacological class, penicillins and tetracyclines were less effective. Tetracyclines have also been cited in other studies, especially in human isolates, with high resistance to this class of antimicrobials [28]; and chicks with different breeding ages showing a gradual increase in resistance with day-old chicks (67\%), 30 days (90\%) and 1-day before slaughter (94\%) [36].

The selective pressure with the consequent permanence of more resistant strains, to the detriment of the indiscriminate use and in greater quantity, of antimicrobial agents in intensive breeding, was pointed out as justification, in a research done, which compared E. coli isolates in subsistence and broiler breeding, and indicated a susceptibility score of $46.6 \%$ (28/60) and $81 \%$ (49/60), respectively [21]. The difference between the results of antimicrobial resistance in the various researches may be related to the routine use of the different antibiotics, once they are used in the treatment and prevention of diseases, where the active principles are chosen according to the protocols adopted in each farm. It is also emphasized that the choice of the antibiotic is carried out empirically, since in some situations antimicrobial susceptibility tests are not performed. 


\section{CONCLUSION}

It is concluded that the meat meal is contaminated by Escherichia coli carrying virulence genes and multiresistant to the antimicrobial agents most used in industrial poultry farming. In this sense, the importance of sanitary control of the inputs used in animal feed is emphasized, as well as the prudent use of these kind of drugs in animal production, with a view to producing a safe food, minimizing not only the economic losses, but also the risks to human health.
MANUFACTURERS

${ }^{1}$ Kasvi Produtos para Laboratórios. Curitiba, PR, Brazil

${ }^{2}$ HiMedia Laboratories Pvt. Ltd. Mumbai, Maharashtra, India.

${ }^{3}$ Cefar Diagnostica Ltda. São Paulo, SP, Brazil.

${ }^{4}$ LGC Biosearch Technologies. Hoddesdon, UK.

${ }^{5}$ Loccus Biotecnologia. Cotia, SP, Brazil.

Declaration of interest. The authors report no conflicts of interest. The authors alone are responsible for the content and writing of the paper

\section{REFERENCES}

1 Abreu D.L.C., Franco R.M., Nascimento E.R., Pereira V.L.A., Alves F.M.X. \& Almeida J.F. 2010. Perfil de sensibilidade antimicrobiana e detecção do gene iss pela reação em cadeia da polimerase e tipificação de Escherichia coli patogênica em codornas de corte sob inspeção sanitária. Pesquisa Veterinária Brasileira. 30(5): 406-410.

2 Almeida M.A.S., Leonídio A.R.A. \& Andrade M.A. 2016. Associação dos quadros anatomopatológicos de colibacilose aviaria com genes de virulência de Escherichia coli. Veterinária em Foco. 13(2): 113-131.

3 Aslam M., Toufeer M., Bravo C.N., Lai V., Rempel H., Manges A. \& Diarra M.S. 2014. Characterization of Extraintestinal Pathogenic Escherichia coli isolated from retail poultry meats from Alberta, Canada. International Journal of Food Microbiology. 2(177): 49-56.

4 Barros M.R. 2011. Epidemiologia molecular das infecções por Mycoplasma spp., Escherichia coli e Staphylococcus spp. em frangos de corte e poedeiras comerciais no estado de Pernambuco. 86f. Recife, PE. Tese (Doutorado em Ciência Veterinária) - Programa de Pós-Graduação em Ciência Veterinária, Universidade Federal Rural de Pernambuco.

5 Barros M.R., Silveira W.D., Araújo J.M., Costa E.P., Oliveira A.A.F., Santos A.P.S.F., Silva V.A.S. \& Mota R.M. 2012. Resistência antimicrobiana e perfil plasmidial de Escherichia coli isolada de frangos de corte e poedeiras comerciais no Estado de Pernambuco. Pesquisa Veterinária Brasileira. 32(5): 405-410.

6 Bergeron C.R, Prussing C., Boerlin P., Daignault D., Dutil L., Reid-Smith R.J., Zhanel G.G. \& Manges A.R. 2012. Chicken as reservoir for extraintestinal pathogenic Escherichia coli in humans, Canada. Emerging Infectious Diseases. 18(3): 415-421.

7 Carli S., Ikuta N., Lehmann F.K.M., Silveira V.P., Predebon G.M., Fonseca A.S.K. \& Lunge V.R. 2015. Virulence gene content in Escherichia coli isolates from poultry flocks with clinical signs of colibacillosis in Brazil. Poultry Science. 94(11): 2635-2640.

8 Carter G.R. 1988. Fontes e transmissão de agentes infecciosos. In: Carter G.R. (Ed). Fundamentos de Bacteriologia e Micologia Veterinária. São Paulo: Roca, pp.65-70.

9 Carvalho D., Tejkowski T.M., Jaenisch F.R.F., Carvalho D., Tejkowski T.M., Jaenisch F.R.F., Rodrigues R.O., Brito K.C.T. \& Brito B.G. 2017. Susceptibilidade de duas linhagens comerciais de frango de corte no desenvolvimento de dermatite necrótica e possível relação dos genes iss e iutA de Escherichia coli com a reprodução experimental da doença. Pesquisa Veterinária Brasileira. 37(12): 1395-1400.

10 Chantziaras I., Boyen F., Callens B. \& Dewulf J. 2014. Correlation between veterinary antimicrobial use and antimicrobial resistance in food-producing animals: a report on seven countries. Journal of Antimicrobial Chemotherapy. 69(3): 827-834.

11 Clinical and Laboratory Standards Institute (CLSI). 2017. Performance Standards for Antimicrobial Susceptibility Testing. Disponível em:<http://www.facm.ucl.ac. be/intranet/CLSI/ CLSI-2017-M100-S27.pdf>. [Accessed online in October 2017].

12 Costa A.R.F., Lima K.V.B., Sousa C.O. \& Loureiro E.C.B. 2010. Desenvolvimento de PCR multiplex para detecção e diferenciação de categorias de Escherichia coli diarreiogênicas. Revista Pan-Amazônica de Saúde. 1(2): 77-84.

13 Danzeisen J.L., Wannemuehler Y., Nolan L.K. \& Johnson T.J. 2013. Comparison of multilocus sequence analysis and virulence genotyping of Escherichia coli from live birds, retail poultry meat and human extraintestinal infection. 
Avian Disease. 57(1): 104-108.

14 Dissanayake D.R., Octavia S. \& Lan R. 2014. Population structure and virulence content of avian pathogenic Escherichia coli isolated from outbreaks in Sri Lanka. Veterinary Microbiology. 168(2-4): 403-412.

15 Gao Q., Jia X., Wang X., Xiong L., Gao S. \& Liu X. 2015. The avian pathogenic Escherichia coli O2 strain E058 carrying the defined aerobactin-defective $i u c D$ or iucDiutA mutation is less virulent in the chicken. Infection, Genetics and Evolution. 30: 267-277.

16 Hussein A.H.M., Ghanem I.A.I., Eid A.A.M., Ali M.A., Sherwood J.S., Li G., Nolan L.K. \& Logue C.M. 2013. Molecular and phenotypic characterization of Escherichia coli isolated from broiler chicken flocks in egypt. Avian Disease. 57(3): 602-611.

17 Jeong Y.W., Kim T.E., Kim J.H. \& Kwon H.J. 2012. Pathotyping avian pathogenic Escherichia coli strains in Korea. Journal of Veterinary Science. 13(2): 145-152.

18 Johnson T.J., Siek K.E., Johnson S.J. \& Nolan L.K. 2006. DNA Sequence of a ColV plasmid and prevalence of selected plasmid-encoded virulence genes among avian Escherichia coli strains. Journal of Bacteriology. 188(2): 745758.

19 Johnson T.J., Wannemuehler Y.M. \& Nolan L.K. 2008. Evolution of the iss gene in Escherichia coli. Applied and Environmental Microbiology. 74(8): 2360-2369.

20 Karami N., Wold A.E. \& Adlerberth I. 2017. Antibiotic resistance is linked to carriage of papC and $i u t A$ virulence genes and phylogenetic group D background in commensal and uropathogenic Escherichia coli from infants and young children. European Journal of Clinical Microbiology \& Infectious Diseases. 36(4): 721-729.

21 Korb A., Nazareno E.R., Costa L.D. \& Nogueira K.S. 2015. Tipagem molecular e resistência aos antimicrobianos em isolados de Escherichia coli de frangos de corte e de tratadores na Região Metropolitana de Curitiba, Paraná. Pesquisa Veterinária Brasileira. 35(3): 258-264.

22 Krumperman P.H. 1983. Multiple antibiotic resistance indexing of Escherichia coli to identify high-risk sources of fecal contamination of foods. Applied and Environmental Microbiology. 46(1): 165-170.

23 Maluta R.P., Logue C.M., Casas M.R., Meng T., Guastalli E.A.L., Rojas T.C.G., Montelli A.C., Sadatsune T., Ramos M.C., Nolan L.K. \& Silveira W.D. 2014. Overlapped sequence types (STs) and serogroups of avian pathogenic (APEC) and human extra-intestinal pathogenic (ExPEC) Escherichia coli isolated in Brazil. Plos One. 9(8): e105016.

24 Marc D. \& Dho-Moulin M. 1996. Analysis of the fim cluster of an avian 02 strain of Escherichia coli: serogroupspecific sites within fimA and nucleotide sequence of firnl. Journal of Medical Microbiology. 44(6): 444-452.

25 Maturana V.G., Pace F., Carlos C., Pires M.M., Campos T.A., Nakazato G., Stheling E.G., Catherine M., Logue C.M., Nolan L.K. \& Silveira W.D. 2011. Subpathotupes of avian pathogenic Escherichia coli (APEC) exist as defined by their syndromes and virulence traits. The Open Microbiology Journal. 5(1): 55-64.

26 Mbanga J. \& Nyararai Y.O. 2015. Virulence gene profiles of avian pathogenic Escherichia coli isolated from chickens with colibacillosis in Bulawayo, Zimbabwe. Onderstepoort Journal of Veterinary Research. 82(1): e1-e8.

27 Mellata M. 2013. Human and avian extraintestinal pathogenic Escherichia coli: infections, zoonotic risks, and antibiotic resistance trends. Foodborne Pathogens and Disease. 10(11): 916-932.

28 Melo D.B., Menezes A.P.O., Reis J.N. \& Guimarães A.G. 2015. Antimicrobial resistance and genetic diversity of Escherichia coli isolated from humans and foods. Brazilian Journal of Microbiology. 46(4): 1165-1170.

29 Mo S.S., Sunde M., Ilag H.K., Langsrud S. \& Heir E. 2017. Transfer potential of plasmids conferring extendedspectrum-cephalosporin resistance in Escherichia coli from poultry. Applied and Environmental Microbiology. 83(12): $1-11$.

30 Murase K., Martin P., Porcheron G., Houle S., Helloin E., Pénary M., Nougayrède J., Dozois C.M., Hayashi T. \& Oswald E. 2016. HlyF produced by extraintestinal pathogenic Escherichia coli is a virulence factor that regulates outer membrane vesicle biogenesis. The Journal of Infectious Diseases. 213(5): 856-865.

31 Oliveira E.S., Cardozo M.V., Montassier M.F.S., Borzi M.M. \& Ávila F.A. 2015. Classificação filogenética e caracterização genotípica dos isolados de Escherichia coli patogênica aviária (APEC) provenientes de galinhas caipiras. In: II Simpósio Internacional de Medicina Veterinária Preventiva (Jaboticabal, Brazil). Ars Veterinaria Journal. 31(2): 32.

32 Rodriguez-Siek K.E., Giddings C.W., Doetkott C.T. \& Johnson J. 2005. Characterizing the APEC pathotype. Veterinary Research. 36(2): 241-256. 
33 Rouger A., Tresse O. \& Zagorec M. 2017. Bacterial contaminants of poultry meat: sources, species, and dynamics. Microorganisms. 5(3): 50.

34 Santos M.M., Alcantara A.C.M., Perecmanis S., Campos A. \& Santana A.P. 2014. Antimicrobial resistance of bacterial strains isolated from avian cellulitis. Revista Brasileira de Ciência Avícola. 16(1): 13-18.

35 Thomassin J.L., Brannona J.R., Gibbs B.F., Gruenheid S. \& Moua H.L. 2012. OmpT outer membrane proteases of enterohemorrhagic and enteropathogenic Escherichia coli contribute differently to the degradation of human LL-37. Infection and Immunity. 80(2): 483-492.

36 Zibandeh S., Sharifiyazdi H., Asasi K. \& Abdi-Hachesoo B. 2016. Investigation of tetracycline resistance genes in Escherichia coli isolates from broiler chickens during a rearing period in Iran. Veterinarski Arhiv. 86(4): 565-572. 